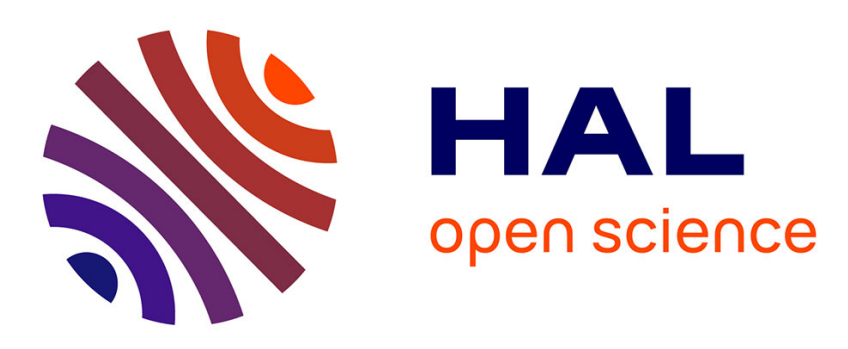

\title{
Investigating Ocean Deoxygenation During the PETM Through the Cr Isotopic Signature of Foraminifera
}

Serginio Remmelzwaal, Sophie Dixon, Ian Parkinson, Daniela Schmidt, Fanny

Monteiro, Philip Sexton, Manuela Fehr, Caroline Peacock, Yannick

Donnadieu, Rachael James

\section{To cite this version:}

Serginio Remmelzwaal, Sophie Dixon, Ian Parkinson, Daniela Schmidt, Fanny Monteiro, et al.. Investigating Ocean Deoxygenation During the PETM Through the Cr Isotopic Signature of Foraminifera. Paleoceanography and Paleoclimatology, 2019, 34 (6), pp.917-929. 10.1029/2018PA003372 . hal02902804

\section{HAL Id: hal-02902804 \\ https://hal.science/hal-02902804}

Submitted on 31 Aug 2021

HAL is a multi-disciplinary open access archive for the deposit and dissemination of scientific research documents, whether they are published or not. The documents may come from teaching and research institutions in France or abroad, or from public or private research centers.
L'archive ouverte pluridisciplinaire HAL, est destinée au dépôt et à la diffusion de documents scientifiques de niveau recherche, publiés ou non, émanant des établissements d'enseignement et de recherche français ou étrangers, des laboratoires publics ou privés.

$$
\text { Copyright }
$$




\section{Paleoceanography and Paleoclimatology}

\section{RESEARCH ARTICLE \\ 10.1029/2018PA003372}

\section{Special Section: \\ Climatic and Biotic Events of the Paleogene: Earth Systems and Planetary Boundaries in a Greenhouse World}

Key Points:

- Chromium isotope variations in foraminifera are controlled by the local redox state

- Deoxygenation during the Palaeocene-Eocene Thermal Maximum caused widespread hypoxia throughout the global oceans

- Ocean water warming cannot fully account for the reported extent of open ocean deoxygenation during the Paleocene Eocene Thermal Maximum

Supporting Information:

- Supporting Information S1

Correspondence to:

S. R. C. Remmelzwaal,

serginio.remmelzwaal@bristol.ac.uk

Citation:

Remmelzwaal, S. R. C., Dixon, S., Parkinson, I. J., Schmidt, D. N., Monteiro, F. M., Sexton, P., et al. (2019) Investigating ocean deoxygenation during the PETM through the $\mathrm{Cr}$ isotopic signature of foraminifera. Paleoceanography and

Paleoclimatology, 34, 917-929. https:// doi.org/10.1029/2018PA003372

Received 28 MAR 2018 Accepted 17 DEC 2018

Accepted article online 3 MAY 2019

Published online 17 JUN 2019

(C)2019. American Geophysical Union. All Rights Reserved.

\section{Investigating Ocean Deoxygenation During the PETM Through the Cr Isotopic Signature of Foraminifera}

\author{
Serginio R. C. Remmelzwaal ${ }^{1}$ iD, Sophie Dixon ${ }^{2}$, Ian J. Parkinson ${ }^{1,2}$, Daniela N. Schmidt ${ }^{1}$, \\ Fanny M. Monteiro ${ }^{3}$, Philip Sexton ${ }^{2}$, Manuela A. Fehr ${ }^{2,4}$, Caroline Peacock $^{5}$, \\ Yannick Donnadieu $^{6,7}$ iD, and Rachael H. James ${ }^{8}$ iD \\ ${ }^{1}$ School of Earth Sciences, University of Bristol, Bristol, UK, ${ }^{2}$ School of Environment, Earth and Ecosystem Sciences, The \\ Open University, Milton Keynes, UK, ${ }^{3}$ School of Geographical Sciences, University of Bristol, Bristol, UK, ${ }^{4}$ Institut für \\ Geochemie und Petrologie, ETH Zürich, Zürich, Switzerland, ${ }^{5}$ School of Earth and Environment, University of Leeds, \\ Leeds, UK, ${ }^{6}$ Laboratoire des Sciences du Climat et de l'Environnement, UMR CNRS-CEA Saclay, Saint-Aubin, France, \\ ${ }^{7}$ Aix-Marseille Université, CNRS, IRD, CEREGE, Aix-en-Provence, France, ${ }^{8}$ Ocean and Earth Science, National \\ Oceanography Centre Southampton, University of Southampton, Southampton, UK
}

Abstract Over the past several decades, oxygen minimum zones have rapidly expanded due to rising temperatures raising concerns about the impacts of future climate change. One way to better understand the drivers behind this expansion is to evaluate the links between climate and seawater deoxygenation in the past especially in times of geologically abrupt climate change such as the Palaeocene-Eocene Thermal Maximum (PETM), a well-characterized period of rapid warming 56 Ma. We have developed and applied the novel redox proxies of foraminiferal $\mathrm{Cr}$ isotopes $\left(\delta^{53} \mathrm{Cr}\right)$ and $\mathrm{Ce}$ anomalies $(\mathrm{Ce} / \mathrm{Ce}$ ) to assess changes in paleoredox conditions arising from changes in oxygen availability. Both $\delta^{53} \mathrm{Cr}$ and $\mathrm{Cr}$ concentrations decrease notably over the PETM at intermediate to upper abyssal water depths, indicative of widespread reductions in dissolved oxygen concentrations. An apparent correlation between the sizes of $\delta^{53} \mathrm{Cr}$ and benthic $\delta^{18} \mathrm{O}$ excursions during the PETM suggests temperature is one of the main controlling factors of deoxygenation in the open ocean. Ocean Drilling Program Sites 1210 in the Pacific and 1263 in the Southeast Atlantic suggest that deoxygenation is associated with warming and circulation changes, as supported by $\mathrm{Ce} / \mathrm{Ce}^{*}$ data. Our geochemical data are supported by simulations from an intermediate complexity climate model (cGENIE), which show that during the PETM anoxia was mostly restricted to the Tethys Sea, while hypoxia was more widespread as a result of increasing atmospheric $\mathrm{CO}_{2}$ (from 1 to 6 times preindustrial values).

\section{Introduction}

As emitted greenhouse gasses accumulate in the atmosphere, temperatures are rising in both the atmosphere and the oceans with unclear consequences for marine ecosystems (Pörtner et al., 2014). One of the hazards associated with global warming is a decrease in oceanic dissolved oxygen content. Over the past 50 years $\mathrm{O}_{2}$ levels have been steadily declining, leading to the expansion of so-called oxygen minimum zones-areas of hypoxic to suboxic levels of $\mathrm{O}_{2}$ at intermediate water depths due to the decreased solubility of $\mathrm{O}_{2}$ and increased metabolic rates of heterotrophic microbes as temperatures rise (Keeling et al., 2010). Understanding the effect of ocean warming on the expansion and intensification of oxygen minimum zones and deep ocean hypoxia is particularly needed (Pörtner et al., 2014). In this study, we assess the development of ocean hypoxia under high temperatures by using extreme warming in the geological past as an analogue for modern anthropogenic warming.

The climate of the Palaeocene and Eocene greenhouse periods experienced several extreme transient warming events of which the largest, the Palaeocene-Eocene Thermal Maximum (PETM; e.g., Cramer et al., 2003) occurred about $56 \mathrm{Ma}$ (Westerhold et al., 2009). The PETM is a particularly pertinent time interval because of its parallels to present-day anthropogenic global warming (Pörtner et al., 2014). Global climate warmed rapidly by $\sim 5{ }^{\circ} \mathrm{C}$ (Dunkley-Jones et al., 2013) within 4,000-20,000 years (Gutjahr et al., 2017; Zeebe et al., 2016), with warming lasting for $200 \mathrm{kyr}$ (Röhl et al., 2007). The cause of the carbon isotope excursion (CIE) toward lighter $\delta^{13} \mathrm{C}$ is still heavily debated (Gutjahr et al., 2017) with much of the literature pointing toward an injection of biogenic methane into the ocean-atmosphere system (e.g., Svensen et al., 2004). The injection of large amounts of carbon resulted in a decrease in alkalinity and intense dissolution of $\mathrm{CaCO}_{3}$ 
(Penman et al., 2016). The estimated change in $\mathrm{pH}$ was about -0.3 units in the surface ocean (Gutjahr et al., 2017; Penman et al., 2014) with an accompanying rise in the calcite compensation depth (CCD) of up to $2 \mathrm{~km}$ in the Atlantic Ocean (Penman et al., 2016; Zachos et al., 2005) though significantly less in the Pacific (>500 m; Colosimo et al., 2006).

The warming of the ocean, increased nutrient runoff, enhanced stratification, and the oxidation of a large body of reduced carbon are all suggested to have reduced oxygen levels in the oceans during the PETM (Chang et al., 2018; Dickson et al., 2012; Nicolo et al., 2010; Pälike et al., 2014). Deoxygenated bottom waters are thought to have been commonplace in marginal settings (e.g., Dickson et al., 2014), and oxygen minimum zones have been suggested to have expanded (Chun et al., 2010; Pälike et al., 2014; Zhou et al., 2016). The presence of geochemical indicators for deoxygenation in the Atlantic, an absence of these in the Pacific Ocean, and the difference in change in the CCD strongly suggest that the carbon source was situated in the Atlantic Ocean (Chun et al., 2010; Pälike et al., 2014; Zhou et al., 2016). We propose here to further investigate the presence and development of hypoxia during the PETM in the Atlantic and Pacific using $\mathrm{Cr}$ isotopes in foraminifera.

Chromium isotopes have received attention in the past few years owing to their potential for reconstructing the paleoredox state of the oceans (e.g., Bonnand et al., 2013; Reinhard et al., 2014). Chromium has multiple valence states and is therefore redox sensitive. In the marine environment, $\mathrm{Cr}$ can occur as either $\mathrm{Cr}$ (III) or $\mathrm{Cr}$ (VI) species, with Cr (VI)-oxyanions the dominant species in oxic seawater (Cranston \& Murray, 1978). Chromium has four stable isotopes of which the difference in the ${ }^{53} \mathrm{Cr} /{ }^{52} \mathrm{Cr}$ ratio compared to National Institute of Standards and Technology SRM979 is reported in the delta notation as $\delta^{53} \mathrm{Cr}_{\text {SRM979, where }}$ $\delta^{53} \mathrm{Cr}_{\text {SRM979 }}=1,000 *\left[\left({ }^{53} \mathrm{Cr} /{ }^{52} \mathrm{Cr}\right)_{\text {sample }}-\left({ }^{53} \mathrm{Cr} /{ }^{52} \mathrm{Cr}\right)_{\text {SRM979 }}\right] /\left({ }^{53} \mathrm{Cr} /{ }^{52} \mathrm{Cr}\right)_{\text {SRM979. As seawater becomes less }}$ oxic, $\mathrm{Cr}$ (VI) will be reduced to $\mathrm{Cr}$ (III), which is removed into oceanic sediments, resulting in lower dissolved $\mathrm{Cr}$ concentrations. The reduction of $\mathrm{Cr}$ is accompanied by a substantial isotope fractionation of up to 7\%o (Ellis et al., 2002). Recent studies have shown that the $\delta^{53} \mathrm{Cr}$ of modern seawater is heterogeneous varying between $0.1 \%$ and $1.8 \%$, which can partly be explained by a short residence time of $\sim 3,000$ years (Goring-Harford et al., 2018; Qin \& Wang, 2017) relative to the average ocean overturning time of $\sim 1,500$ years. There appears to be a negative correlation between $[\mathrm{Cr}]$ and $\delta^{53} \mathrm{Cr}$ in seawater samples measured to date (Paulukat et al., 2016; Scheiderich et al., 2015) that has been attributed to partial reduction of $\mathrm{Cr}$ (VI) in surface waters and oxygen minimum zones (with a $\Delta_{\mathrm{Cr}(\mathrm{III})-\mathrm{Cr}(\mathrm{VI})}$ of $-0.79 \%$ ), coupled with $\mathrm{Cr}$ (III) reoxidation in deep waters (Paulukat et al., 2016; Scheiderich et al., 2015).

Experimental data and studies on carbonates show that $\mathrm{Cr}$ is incorporated into the calcite lattice of carbonates (Bonnand et al., 2013; Tang et al., 2007) as a chromate ion and therefore marine carbonate records can be used as a potential archive for seawater Cr. A recent investigation into seawater controls on the $\mathrm{Cr}$ isotopic composition of core-top foraminifera (Wang et al., 2017) left open questions as to what might drive incorporation of $\mathrm{Cr}$ into foraminifera. No direct calibrations of this proxy in foraminiferal calcite have been performed. However, recent work has shown that while some $\mathrm{Cr}$ is incorporated during calcification most $\mathrm{Cr}$ in sedimentary foraminifera has a postdepositional origin and therefore will record bottom and pore water Cr compositions (Remmelzwaal et al., 2019). Remmelzwaal et al. (2019) also demonstrated that foraminiferal $\delta^{53} \mathrm{Cr}$ values are not species dependent but rather dependent on foraminiferal test size meaning that the surface area/volume ratio controls $\mathrm{Cr}$ exchange between the test and bottom water and/or sediment pore waters. Questions around the empirical relationship between $\delta^{53} \mathrm{Cr}$ and $\left[\mathrm{O}_{2}\right]$ as well as potential dissolution effects remain unanswered. We thus interpret $\delta^{53} \mathrm{Cr}$ data here in a qualitative sense, in terms of the sign of change, as an indicator of bottom and pore water ocean deoxygenation.

To better constrain bottom water ocean deoxygenation during the PETM, we combine Cr isotope data with measurements of cerium (Ce), a potentially useful rare earth element (REE) to reconstruct oxidation states (e.g., Zhou et al., 2016). Unlike most REEs, Ce has two oxidation states, Ce (III) and Ce (IV), and like Cr is redox sensitive. Modern seawater has a characteristic negative Ce anomaly. This anomaly has been suggested to have been caused by the oxidation of Ce (III) to the insoluble and particle-reactive Ce (IV) in surface waters and estuaries where seawater is consequently depleted in Ce with respect to $\mathrm{La}, \mathrm{Pr}$, and $\mathrm{Nd}$ (De Baar et al., 1988). In anoxic waters Ce concentrations are high and the Ce anomaly vanishes or even becomes slightly positive (De Baar et al., 1988). Ce/Ce* values (defined in section 2.3.2) are approximately 1.0 in anoxic seawater, $0.5-1.0$ in hypoxic pore waters and lower than 0.5 for oxic seawater (Zhou et al., 
2016). Foraminiferal cerium mostly resides in authigenic ferromanganese coatings that form after sediment deposition (Palmer, 1985).

In this study, we investigate the development of open ocean deoxygenation during the PETM using the foraminiferal redox proxies $\delta^{53} \mathrm{Cr}$ and $\mathrm{Ce} / \mathrm{Ce}$. We compare our data with published geochemical, sedimentological, and micropalaeontological studies that inform on redox conditions during the PETM. We also perform some ocean biogeochemical model simulations; this model-data comparison allows us to assess the evolution of ocean deoxygenation in intermediate and upper abyssal waters and the extent to which the oceans experienced hypoxia and anoxia.

\section{Material and Methods}

\subsection{Sample Site Selection}

Our geochemical data are derived from three sites drilled by the Deep Sea Drilling Program (DSDP) and Ocean Drilling Program (ODP): DSDP Site 401 is located in the Bay of Biscay (northeastern Atlantic) with a paleodepth of $1,900 \mathrm{~m}$, ODP Site 1263 is on Walvis Ridge (southeastern Atlantic) with a palaeodepth of 1,500 m, and ODP Site 1210 is on Shatsky Rise (North Pacific) with a palaeodepth of 2,400 m (Figure 1; Pälike et al., 2014, and references therein). Site 1210 is located in the North Pacific where more vigorous deep water formation has been suggested to have occurred during the PETM (Lunt et al., 2010; Tripati \& Elderfield, 2005), whereas a slowdown purportedly occurred in the South Atlantic (Site 1263; Tripati \& Elderfield, 2005). It must be noted, however, that there is no consensus on the site of deep water formation during the PETM with the North Atlantic as location of downwelling (Alexander et al., 2015; Bice \& Marotzke, 2002; Nunes \& Norris, 2006). Site 1263 was located near a major oxygen minimum zone (Chun et al., 2010). Site 401 was in the comparatively narrow North Atlantic that was gradually widening in association with major volcanic activity during the Palaeocene-Eocene (Svensen et al., 2004).

\subsection{Age Models}

Age models were derived from the cyclostratigraphic analyses by Gutjahr et al. (2017) for Site 401, Westerhold et al. (2008) for Site 1210, and Röhl et al. (2007) for Site 1263. These were anchored to a timescale following the age constraint of the PETM by Westerhold et al. (2009). Linear sedimentation rates were used to calculate the ages for all the data plotted.

\subsection{Analytical Methods}

\subsubsection{Sample Processing}

Sediment samples $(n=87)$ of $10-20 \mathrm{~cm}^{3}$ were wet sieved with a $63-\mu \mathrm{m}$ sieve. Coarse fractions are the dry mass of the particles larger than $63 \mu \mathrm{m}$ as the weight percentage of the dry mass of the total sample prior to sieving. A mixture of planktic foraminiferal species (Morozovella spp., Acarinina spp., and Subbotina spp.) was picked from these samples to obtain approximately 1,000 specimens (or about $0.11 \mathrm{~g}$ ). At Sites 1210 and 1263, foraminifera are moderately well preserved before the PETM, but preservation rapidly deteriorates during the onset of the CIE and improves again during the CIE recovery (Kelly et al., 2005; Petrizzo, 2007). At Site 401, foraminifera are generally well preserved throughout the studied interval (Pardo et al., 1997). Samples were cleaned by gently cracking open the foraminiferal tests, with subsequent removal of clay particles and organic matter by ultrasonication in Milli-Q (MQ) grade water and by leaching in alkali buffered $\mathrm{H}_{2} \mathrm{O}_{2}$, respectively (Barker et al., 2003). Analysis of the chemical composition of marine Fe-Mn-rich crusts shows that these have relatively low Cr concentrations (16-47-ppm Cr; Hein \& Koschinsky, 2014), and therefore, the Fe-Mn coatings were not removed to preserve as much of the calcite as possible for analysis (Remmelzwaal et al., 2019).

\subsubsection{Trace Element Analysis}

Cleaned samples of $\sim 0.01 \mathrm{~g}$ were dissolved in cold 0.5-M acetic acid, dried down to incipient dryness and subsequently were dissolved and diluted with $2 \% \mathrm{HNO}_{3}$ acid by $\sim 4,000$ times to produce a 100-ppm Ca solution. A suite of synthetic standards containing 40 trace elements at a variety of concentrations and doped with 100-ppm Ca were used to produce a calibration curve. REEs and $\mathrm{Cr}$ concentrations were measured in $\mathrm{He}$ and $\mathrm{O}_{2}$ collision mode respectively on an Agilent 7500s ICP-QQQ-MS (Triple Quadrupole ICP-MS) at the Open University. REE concentrations are normalized to Post Archaean Australian Shale (PAAS) concentrations (Taylor \& McLennan, 1985). Anomalies in Ce are expressed as $\mathrm{Ce} / \mathrm{Ce}^{*}=$ 


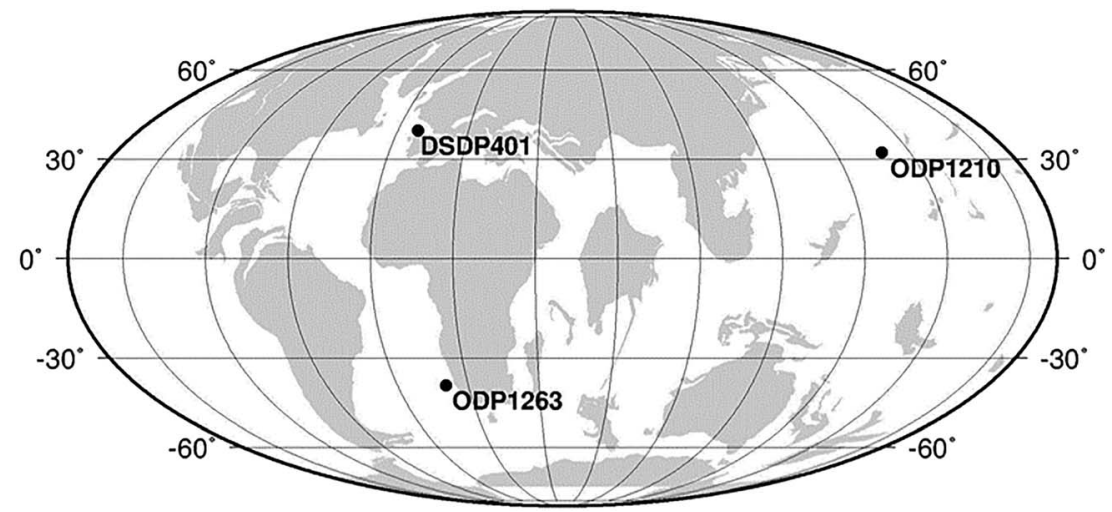

Figure 1. Palaeogeographic reconstruction for $56 \mathrm{Ma}$ (www.odsn.de) with sample sites marked.

$\left(\mathrm{Ce} / \mathrm{Ce}_{\mathrm{PAAS}}\right) /\left[\mathrm{Pr} / \operatorname{Pr}_{\mathrm{PAAS}} *\left(\mathrm{Pr} / \mathrm{Pr}_{\mathrm{PAAS}}\right) /\left(\mathrm{Nd} / \mathrm{Nd}_{\mathrm{PAAS}}\right)\right]$ (Tostevin et al., 2016). Measurements are reproducible within $\sim \pm 2 \%$ for $\mathrm{Cr}$ and $\sim \pm 9 \%$ for $\mathrm{Ce} / \mathrm{Ce} *$ based on replicate analysis of the carbonate standard reference material JDo-1.

\subsubsection{Chromium Isotope Analysis}

Approximately 0. $\mathrm{g}$ of sample (down to $0.03 \mathrm{~g}$ during the height of the dissolution event at ODP Site 1263) was dissolved by ultrasonication in $0.5-\mathrm{M}$ acetic acid to prevent any potential leaching of any remaining detrital material left after cleaning. Chromium was subsequently extracted following the cation exchange chromatographic separation procedures described in Bonnand et al. (2011) with procedural blank $\mathrm{Cr}$ contributions of $\sim 0.2 \mathrm{ng}$. JDo- 1 was subjected to the same chemistry protocol as the samples. Chromium isotopes were measured on a ThermoFisher Scientific Neptune MC-ICP-MS at the University of Bristol by using a ${ }^{50} \mathrm{Cr}^{54} \mathrm{Cr}$ double-spike technique following Bonnand et al. (2011). The average value obtained for JDo- 1 is $\delta^{53} \mathrm{Cr}=1.715 \pm 0.059(2 \sigma, n=8)$, which is within error of previously published values of $\delta^{53} \mathrm{Cr}=$ $1.719 \pm 0.059$ (Bonnand et al., 2011). The external reproducibility of National Institute of Standards and Technology SRM 979 is $\delta^{53} \mathrm{Cr}=0.002 \pm 0.026(2 \sigma, n=20)$.

\section{4. cGENIE Modeling Setup}

To estimate the global extent of deoxygenation during the PETM, we compare proxy observations of ocean redox state with model simulations of the Paleogene ocean following the approach described in Monteiro et al. (2012). The model employed was the Earth system model of intermediate complexity cGENIE, a 3-D ocean biogeochemical model coupled to a 2-D atmospheric model (Ridgwell et al., 2007). Marine productivity is modeled in cGENIE through the activity of both nonfixing phytoplankton and diazotrophs, where productivity is limited by light, temperature and nutrient concentrations of phosphate and fixed nitrogen (nitrate and ammonium). cGENIE lets nitrogen fixation occur when fixed nitrogen is smaller than a dynamical threshold for oligotrophy, which accounts for resource competition. The nitrogen cycle also includes the nitrification process of oxidation of ammonium into nitrate (Monteiro et al., 2012). In the model, denitrification occurs when oxygen concentrations drop below $30 \mu \mathrm{mol} \mathrm{O} 2 / \mathrm{L}$, which is higher than modern values due to the low model resolution (Monteiro et al., 2012). In cGENIE, the remineralization of particulate organic matter follows a double exponential decrease with depth, which depends on the availability of oxygen, nitrate and sulfate (Ridgwell et al., 2007). Any particulate organic matter reaching the seafloor is instantaneously remineralized into inorganic matter, as no sediments are included in the model. We configured cGENIE for the Eocene using bathymetry and continental configuration derived from the higherresolution model Fast Ocean Atmosphere Model simulations. The annual average wind field transformed to the cGENIE grid came from the Eocene Fast Ocean Atmosphere Model experiment run with $4 \mathrm{x} \mathrm{CO}_{2}($ relative to the preindustrial atmospheric value). cGENIE biogeochemistry accounted for carbon, phosphorus, nitrogen, oxygen, and sulfur cycling as described by Monteiro et al. (2012), including equations and parameter values for ocean productivity and temperature control.

We ran the model under different environmental forcings, varying the oceanic phosphate inventory and atmospheric $\mathrm{CO}_{2}$ to investigate the impact of changes in nutrient supply and temperature on oceanic 

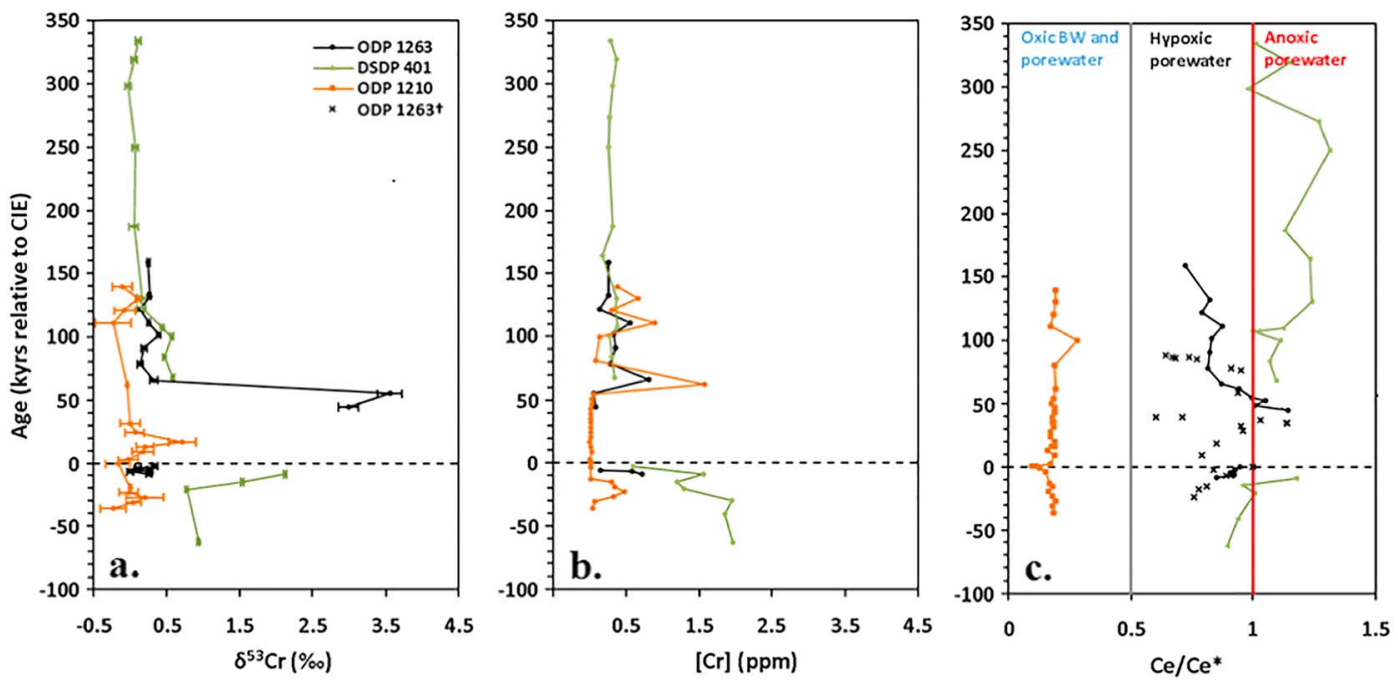

Figure 2. Records for Sites 401, 1210, and 1263 across the PETM of (a) $\delta^{53} \mathrm{Cr}(\%)$ show large differences in timing and size between the $\delta^{53} \mathrm{Cr}$ excursions (b) chromium concentrations (ppm). (c) Cerium anomalies show that northwest Pacific bottom waters were oxic and Atlantic bottom waters were hypoxic. Ce/Ce* above 1 indicates anoxic conditions and below 0.5 bottom waters are oxic (Haley et al., 2004). ${ }^{\dagger}$ Fish tooth Ce/Ce* data for ODP 1263 by Zhou et al. (2016). The dotted line corresponds to the onset of the CIE associated with the PETM. Tabled geochemical data can be found in supporting information A. BW $=$ bottom water; DSDDeep Sea Drilling Program; ODOcean Drilling Program; PETM = Palaeocene-Eocene Thermal Maximum.

oxygen levels during the PETM. As found in Monteiro et al. (2012), the model shows that ocean oxygen levels at the Eocene were more sensitive to changes in phosphate inventory than changes in atmospheric $\mathrm{CO}_{2}(\mathrm{see}$ supporting information B). The model results are then compared with published data and data generated in this study for seawater deoxygenation and photic zone euxinia across the PETM (Carmichael et al., 2017, Tables B5 and B6).

We calculate a score of agreement between the model results and data for before and during the PETM (0-1, where 0 indicates no agreement and 1 indicates perfect agreement; Monteiro et al., 2012). Here, we add the distinction between anoxia/suboxia ( $<10-\mu \mathrm{M} \mathrm{O}_{2}$; Diaz \& Rosenberg, 2008) and hypoxia (10-60- $\mu \mathrm{M} \mathrm{O}_{2}$; Diaz \& Rosenberg, 2008; Vaquer-Sunyer \& Duarte, 2008) to better capture the subtler deoxygenation that is thought to have taken place during the PETM in comparison to Mesozoic ocean anoxic events (OAEs). The geographical extent of photic zone euxinia has been assessed with a threshold of $>0-\mu \mathrm{M} \mathrm{H}_{2} \mathrm{~S}$ (Monteiro et al., 2012). See supporting information B for a full description of the agreement calculation.

\section{Results}

\subsection{Chromium and Cerium Anomalies}

DSDP Site 401, located in the North Atlantic, shows a rapid increase in foraminiferal $\delta^{53} \mathrm{Cr}$ of about $1.4 \%$ o paired with a decrease in [Cr] of about 1.5 ppm just prior to the CIE (Figure 2). No Cr isotope data are available for the onset of the PETM itself as this was an interval of intense dissolution. This dissolution has led to a condensed section where not enough foraminifera could be obtained for analysis. The highest $\delta^{53} \mathrm{Cr}$ values are prior to the onset of the CIE and they recovered to background values 68 kyr after the CIE onset. Chromium concentrations reach their lowest values of $0.27 \mathrm{ppm}$ prior to the CIE minimum and do not recover within our 400-kyr record. The severe carbonate dissolution at ODP Site 1263 (Walvis Ridge, South Atlantic), as indicated by a steep drop of $\sim 4.8 \%$ in the coarse fraction (CF; all material $>63 \mu \mathrm{m}$ ), a monitor of $\mathrm{CaCO}_{3}$ dissolution through this interval, meant that our foraminiferal analysis was unable to capture the onset of the event (Figure 3). While $\mathrm{Cr}$ concentrations are highly variable prior to the PETM and after peak-CIE conditions, $[\mathrm{Cr}]$ attains its lowest values during the peak of the CIE. The timing of the crash and recovery in [Cr] corresponds with that of the CF record (Figures 2 and 3).

In the Pacific basin, at ODP Site 1210 (Shatsky Rise) the Cr concentrations are extremely low (down to 0.01 ppm) during the PETM and decrease prior to the CIE. Chromium concentrations are variable prior to the 

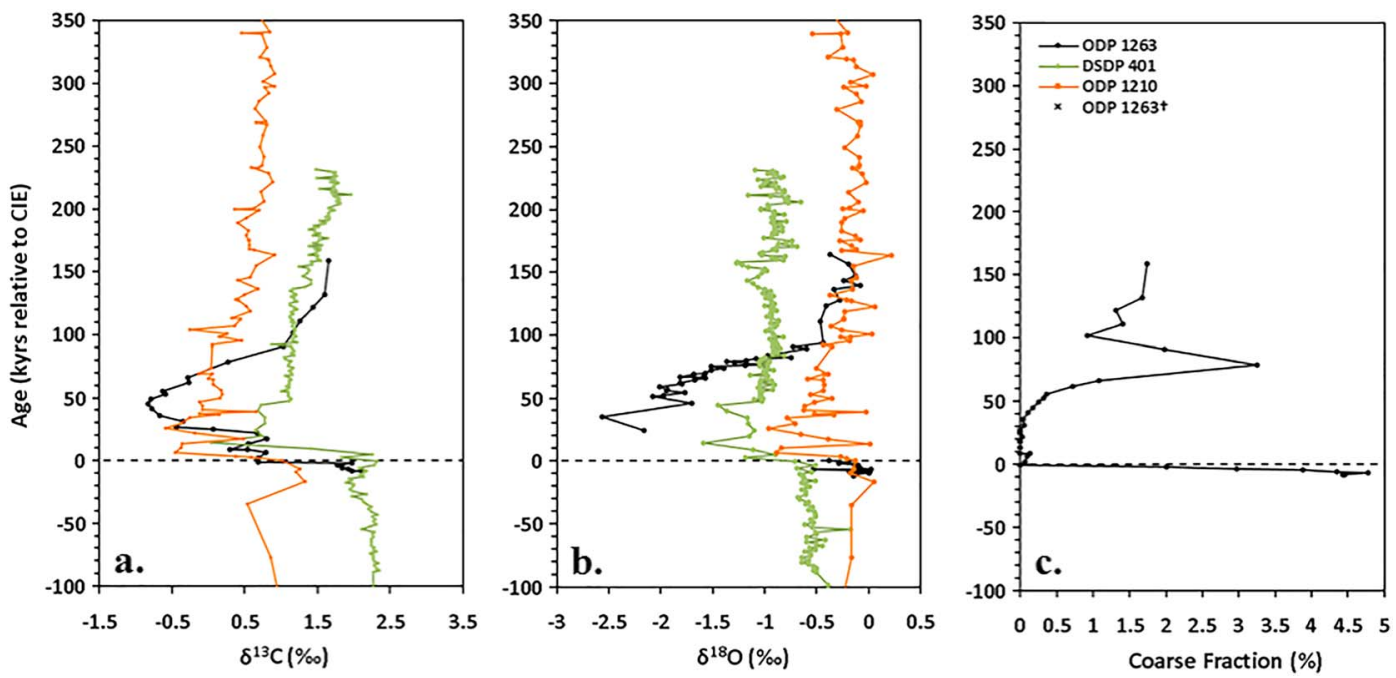

Figure 3. Records for Sites 401, 1210, and 1263 across the PETM of (a) benthic $\delta^{13} \mathrm{C}(\%)$ for Sites 401 and 1210 (Nunes \& Norris, 2006; Westerhold et al., 2011), bulk $\delta^{13} \mathrm{C}(\%)$ for Site 1263 (Zachos et al., 2005). (b) Benthic $\delta^{18} \mathrm{O}(\%)$ from N. truempyi (Nunes \& Norris, 2006; McCarren et al., 2008; Westerhold et al., 2011). (c) Coarse fraction $(>63 \mu \mathrm{m})$ at Site 1263; a measure of $\mathrm{CaCO}_{3}$ dissolution, measured for this study and in agreement with high-resolution records by Kelly et al. (2010). The dotted line corresponds to the onset of the carbon isotope excursion associated with the PETM. DSDDeep Sea Drilling Program; ODOcean Drilling Program; PETM = Palaeocene-Eocene Thermal Maximum.

PETM and during the carbon isotope recovery at this site. The maximum $\delta^{53} \mathrm{Cr}$ value at ODP Site 1210 is $0.71 \%$ with the highest $\delta^{53} \mathrm{Cr}$ values occurring approximately $20 \mathrm{kyr}$ after the onset of the PETM in the middle of the $\delta^{18} \mathrm{O}$ excursion (Figures 2 and 3). This pattern is unlike the observations at DSDP Site 401, where $\delta^{53} \mathrm{Cr}$ values shift before the onset of the PETM.

Foraminiferal cerium anomalies of 0.10-0.28 (Figure 2) confirm previous findings that the North Pacific Ocean is more oxygenated than the Atlantic Ocean with values at ODP Site 1263 of 0.72-1.14 falling within the range found by Zhou et al. (2016). Cerium anomalies of 0.60-1.31 at Site 401 suggest that North Atlantic bottom and pore waters were severely hypoxic and potentially anoxic.

\subsection{Three-Dimensional Model-Data Comparison}

We reconstructed the change in deoxygenation across the PETM by comparing the data as compiled by Carmichael et al. (2017), Tables B5 and B6) and results from this study with the cGENIE model results. The best model fit to the data for pre-PETM conditions is achieved with the modern oceanic phosphate inventory $\left(1 \times \mathrm{PO}_{4}\right)$ and 1-2 times preindustrial atmospheric $\mathrm{CO}_{2}\left(1-2 \times \mathrm{CO}_{2}\right.$; Table $\left.\mathrm{B} 1\right)$. The best model fit for the PETM is achieved under $1 \times \mathrm{PO}_{4}$ and $6 \times \mathrm{CO}_{2}$ conditions (Table B4 and Figure 4) and falls within the estimated $p \mathrm{CO}_{2}$ for the PETM (e.g., Gutjahr et al., 2017; Schubert \& Hope Jahren, 2013). In our model, the Tethys Sea and North Atlantic experience hypoxic to suboxic conditions (Figure 4) even with preindustrial forcings while significantly less deoxygenation occurs in the eastern Pacific and Southern Ocean.

\section{Discussion}

\subsection{Global Ocean Deoxygenation Patterns}

Our model-data comparison indicates that the Tethys Sea and North Atlantic Ocean both experienced hypoxia to suboxia (Figure 3), even during pre-PETM conditions. While anoxia/suboxia seems to be restricted to the Tethys Sea before and during the PETM, hypoxia spread from the North Atlantic Ocean and some part of the South Atlantic Ocean to the Eastern Pacific Ocean. The Tethys Sea is the only ocean basin that experienced extensive photic zone euxinia (Figure 4). According to our reconstruction across the PETM, hypoxia rose by $15 \%$ to reach $27 \%$ of the global ocean volume and anoxia/suboxia rose by $2 \%$ to reach $4 \%$ of the global ocean volume by varying the $\mathrm{CO}_{2}$ forcings in the model from 1 to $6 \times \mathrm{CO}_{2}$ (Table 1). 


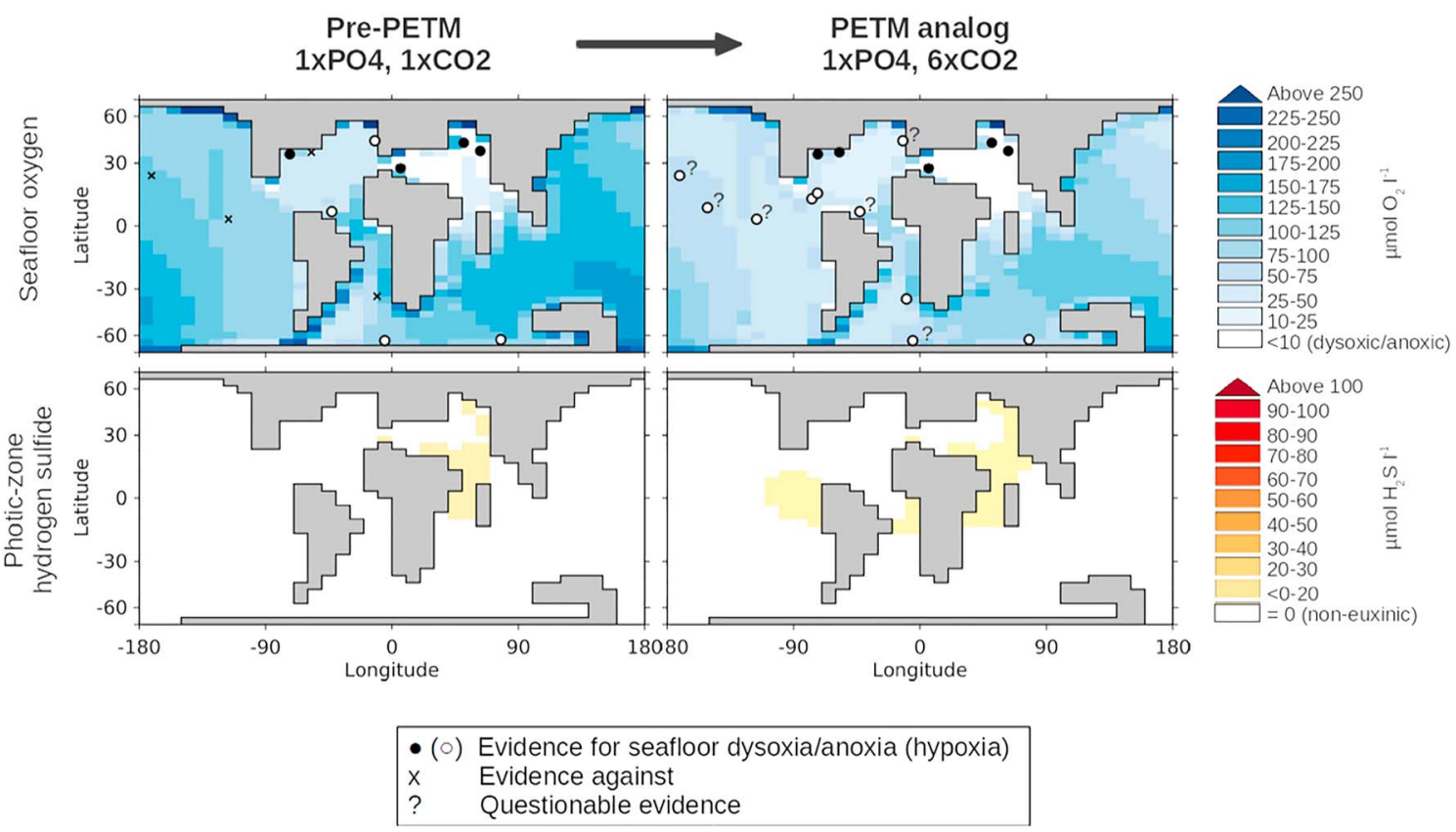

Figure 4. cGENIE model result for the best fit conditions for both before and during the PETM plotted with evidence for oxic seafloor environments (cross), seafloor hypoxia (open circle), and seafloor anoxia (filled circle). Nonconclusive sets of evidence have been marked by a question mark. The best model-data fits were achieved under $1 \mathrm{x}$ preindustrial $\mathrm{CO}_{2}$ values $\left(1 \mathrm{x} \mathrm{CO}_{2}\right)$ and $6 \mathrm{x}$ preindustrial $\mathrm{CO}_{2}$ values $\left(6 \mathrm{x} \mathrm{CO}_{2}\right)$ in the model. References for data points can be found in Carmichael et al. (2017) and include $\mathrm{Cr}$ and Ce data from this study in addition. Model results indicate that up to $31 \%$ of the global ocean volume may have experienced hypoxic to anoxic conditions and suggest widespread open ocean deoxygenation took place during the PETM, whereas photic zone euxinia would have been restricted to the Eastern Tethys Sea and eastern boundary upwelling zones. PETM = Palaeocene-Eocene Thermal Maximum.

There is considerable evidence for widespread seafloor anoxia in the Tethys during the PETM (see Carmichael et al., 2017, for a recent compilation; Table 2). Along the northern margins of the Tethys Sea, there is also evidence for persistent photic zone euxinia (e.g., Dickson et al., 2014) and intermittent euxinia along the southern and eastern margins during the PETM (Carmichael et al., 2017). The highly reduced state of the Tethys Sea during the PETM is captured by our model that also indicates the presence of strong photic zone euxinia in the Eastern Tethys (Figure 4). Our model-data comparison also suggests that low-oxygen environments were present in the Tethys Sea prior to the PETM. Due to its restricted water exchange and relative proximity to land, the Tethys Sea could have acted as a trap for nutrients causing high productivity leading to anoxic to euxinic conditions (Carmichael et al., 2017).

In contrast to the Tethys Sea, the Atlantic Ocean was more oxygenated before and during the PETM (Figure 4). Regionally, the North Atlantic was already hypoxic prior to the PETM whereas the South Atlantic was mostly oxic representing the more restricted North Atlantic versus the more oxygenated South Atlantic due to the proposed location of bottom water formation (Tripati \& Elderfield, 2005). Neodymium isotope data suggest that there was limited water exchange between the North and South Atlantic (Abbott et al., 2016).

Table 1

Summary of the Findings of the cGENIE Model-Data Comparison From This Study on the Percentage Change in the Global Ocean's Oxygenation State Associated With the PETM

\begin{tabular}{lcc}
\hline & \multicolumn{2}{c}{ Ocean volume (\%) } \\
\cline { 2 - 3 } Oxygenation state & Pre-PETM & PETM \\
\hline Anoxia/dysoxia & 2 & 4 \\
Hypoxia & 12 & 27 \\
Euxinia & 4 & 8 \\
\hline
\end{tabular}

Note. PETM $=$ Palaeocene-Eocene Thermal Maximum
Our model-data comparison indicates that the Pacific Ocean was well oxygenated prior to the PETM, except for the area off the western coast of South America (Figure 4), where analogous to today, the deflection of waters would have resulted in upwelling, nutrient enrichment and high productivity. However, in agreement with $\mathrm{Cr}$ isotope data, our model runs shows widespread reductions in dissolved oxygen content to hypoxic levels in the East Pacific during the PETM. This challenges the idea that the PETM was geographically substantially less widespread than the Mesozoic OAEs (Carmichael et al., 2017), although the overall decrease in oxygen concentrations is modest in comparison to, for example, OAE 2 (Monteiro et al., 2012). 
Table 2

Summary of Findings for the Palaeoredox State of the Bottom Waters at Intermediate Water Depths During the PETM at DSDP Site 401 and ODP Sites 1210 and 1263

\begin{tabular}{|c|c|c|c|c|}
\hline Location & Method & Pre-PETM & PETM & Post PETM \\
\hline \multirow{4}{*}{$\begin{array}{l}\text { DSDP Site } 401 \text { Bay of Biscay } \\
\text { (North Atlantic) }\end{array}$} & $\mathrm{Ce} / \mathrm{Ce}^{*}$ & Hypoxic & Anoxic & Anoxic \\
\hline & $\delta^{53} \mathrm{Cr}$ & Oxic & Hypoxic Anoxic & Oxic? \\
\hline & cGENIE & Oxic & Hypoxic & - \\
\hline & $\mathrm{Mn}_{\mathrm{EF}}$ and $\mathrm{U}_{\mathrm{EF}}^{\mathrm{a}}$ & Suboxic & Suboxic & Suboxic \\
\hline \multirow{4}{*}{$\begin{array}{l}\text { ODP Site } 1210 \text { Shatsky Rise } \\
\text { (Pacific) }\end{array}$} & $\mathrm{Ce} / \mathrm{Ce}^{*}$ & Oxic & Oxic & Oxic \\
\hline & $\delta^{53} \mathrm{Cr}$ & Oxic & Oxic & Oxic \\
\hline & cGENIE & Oxic & Oxic & - \\
\hline & $\mathrm{Mn}_{\mathrm{EF}}$ and $\mathrm{U}_{\mathrm{EF}}^{\mathrm{a}}$ & Oxic & Oxic & Oxic \\
\hline \multirow{4}{*}{$\begin{array}{l}\text { ODP Site } 1263 \text { Walvis Ridge } \\
\text { (South Atlantic) }\end{array}$} & $\mathrm{Ce} / \mathrm{Ce}^{*}$ & Hypoxic & Anoxic & Hypoxic \\
\hline & $\delta^{53} \mathrm{Cr}$ & Oxic & Hypoxic Anoxic & Oxic \\
\hline & cGENIE & Oxic & Нypoxic & - \\
\hline & $\mathrm{Mn}_{\mathrm{EF}}$ and $\mathrm{U}_{\mathrm{EF}}^{\mathrm{a}}$ & Suboxic & Suboxic & Suboxic \\
\hline
\end{tabular}

Note. Interpretations of the redox state are based on $\mathrm{Ce} / \mathrm{Ce}^{*}$ and $\delta^{53} \mathrm{Cr}$ results from this study, cGENIE model-data comparison results from this study. As the cGENIE model is spun-up toward a steady state, there is no "post"-PETM assessment possible. DSDP = Deep Sea Drilling Program; ODP = Ocean Drilling Program; PETM = Palaeocene-Eocene Thermal Maximum.

${ }^{\mathrm{a}} \mathrm{Mn} \mathrm{EF}_{\mathrm{F}}$ and $\mathrm{U}_{\mathrm{EF}}$ results are from Pälike et al. (2014).

Our $\mathrm{Cr}$ isotope and concentration records are different both stratigraphically and in excursion size at the three sites and suggest a local redox control. Therefore, variations in $\delta^{53} \mathrm{Cr}$ values do not necessarily represent a global signal. We suggest that a range of mechanisms were responsible for the differences in the $\delta^{53} \mathrm{Cr}$ records between the sites, which we will explore in further detail in the following sections.

Published seawater data show that modern seawater $\delta^{53} \mathrm{Cr}$ measurements are distributed within the range of 0.1-1.8\% with a median value of 1.2\%o (Bonnand et al., 2013; Economou-Eliopoulos et al., 2016; GoringHarford et al., 2018; Holmden et al., 2016; Paulukat et al., 2016; Pereira et al., 2016; Scheiderich et al., 2015). Open ocean intermediate and deep waters have a relatively constant $\delta^{53} \mathrm{Cr}$ signature (GoringHarford et al., 2018). Less oxygenated waters are expected to have a heavier $\delta^{53} \mathrm{Cr}$ due to partial isotopic fractionation under more reducing conditions (Ellis et al., 2002). Therefore, one may expect intermediate and deep water $\delta^{53} \mathrm{Cr}$ to reflect changes in redox state which should be reflected by foraminiferal calcite (Goring-Harford et al., 2018; Remmelzwaal et al., 2019). The $\delta^{53} \mathrm{Cr}$ values for the PETM at ODP Site 1210 fall within the oxic and hypoxic range (Goring-Harford et al., 2018). Peak Cr isotope values at DSDP Site 401 and ODP Site 1263 are higher than the modern range for oxic and hypoxic seawater. We assume that this implies that ODP Site 1263 and DSDP 401 might yield Cr isotope values that can be interpreted as reflecting hypoxicanoxic conditions during the PETM, whereas the Pacific recorded minor deoxygenation within the upper bounds of modern oxic seawater. These findings are consistent with Ce anomalies, which suggest that the North Pacific remained oxic in contrast to the North and South Atlantic (Figure 2).

\subsection{Deoxygenation Through Ocean Circulation Changes}

A switch to warmer, more corrosive and less oxygenated intermediate waters at Walvis Ridge in the South Atlantic, as postulated by Lunt et al. (2010) can explain the correlation between $\delta^{53} \mathrm{Cr}$, $[\mathrm{Cr}]$, and the $\mathrm{CF}$ record at ODP Site 1263 (generated for this study and in agreement with the higher-resolution CF record by Kelly et al., 2010), and the intensified carbonate dissolution this represents (Figure 3). While there is no agreement about the circulation switch (e.g., Alexander et al., 2015; Nunes \& Norris, 2006), it is thought that during the latest Palaeocene, deep ocean formation in the Southern Ocean decreased while a new circulation cell developed in the North Pacific (Tripati \& Elderfield, 2005). During the PETM an abrupt switch to North Pacific convection and a salinity-stratified ocean occurred leading to substantial warming of intermediate and deep waters (Lunt et al., 2010; Tripati \& Elderfield, 2005). Additional evidence for fundamental changes in intermediate and deep water circulation during the latest Palaeocene and PETM comes from Nd isotopes that suggest changes in deep water circulation started prior to PETM warmth (Abbott et al., 2016). Model simulations of bottom water circulation during the PETM show that corrosive bottom waters built up in the North Atlantic and flowed to the South Atlantic during the PETM 
(Alexander et al., 2015). This is, however, in disagreement with the Nd isotope data, which suggests a more limited exchange of waters between ocean basins (Abbott et al., 2016). The warming of South Atlantic intermediate and deep waters would trigger a reduction in oxygen concentrations and could provide an explanation for the response in $\mathrm{Cr}$ isotopes. The extraordinarily high $\delta^{53} \mathrm{Cr}$ at ODP Site 1263 $(\sim+3.5 \%$ o $)$ can be partly attributed to partial reduction associated with the expansion of a major oxygen minimum zone off the West-African coast into intermediate waters as suggested by Mn and $U$ enrichment factors (EF; Chun et al., 2010). Unlike the $\mathrm{Mn}_{\mathrm{EF}}$ and $\mathrm{U}_{\mathrm{EF}}$ at ODP Site 1263 (Chun et al., 2010) and our Ce/Ce* results (Figure 2), the $\delta^{53} \mathrm{Cr}$ record at Site 1263 does not provide any evidence for hypoxia prior to or after the CIE (Figure 2) leaving open questions and disagreement with previous studies (Chun et al., 2010; Pälike et al., 2014; Zhou et al., 2016). This potentially signifies that $\mathrm{Cr}$ and Ce have different oxygen concentration thresholds to $\mathrm{Mn}$ and $\mathrm{U}$ below which these become redox reactive. This is partially captured by different standard reduction potentials at seawater $\mathrm{pH}$ levels for $\mathrm{Cr}, \mathrm{Ce} \mathrm{Mn}$, and $U$ (Brookins, 1988).

The Ce/Ce* at ODP Site 1263 peaks when our measured $\delta^{53} \mathrm{Cr}$ values are highest, around 40 kyr after the onset of the PETM, and subsequently recovers to values indicative of near oxic conditions. The Ce/Ce* record at ODP Site 1263 by Zhou et al. (2016) also peaks approximately $35 \mathrm{kyr}$ after the CIE at anoxic values. However, our foraminiferal cerium anomalies show a clearer pattern of decreasing oxygen levels prior to the PETM and a recovery afterward than the $\mathrm{Ce} / \mathrm{Ce}^{*}$ from fish teeth, although the latter are recorded throughout the PETM unlike the foraminiferal data due to carbonate dissolution (Zhou et al., 2016). Geochemical evidence exists for oxic conditions at the nearby deeper ODP Site 1262 (Chun et al., 2010; Zhou et al., 2016), although it is thought transient hypoxia did occur in the carbonate-free interval at ODP Site 1262 (Post et al., 2016). This suggests that deoxygenation mainly occurred at intermediate depths in the South Atlantic, and less so deeper in the water column.

Our model-data comparison and $\mathrm{Cr}$ isotope data support oxic bottom water conditions before the PETM at ODP Site 1263 in the South Atlantic (Figure 4) in line with a more intense deep convection in the Southern Ocean prior to and after the PETM (Lunt et al., 2010; Nunes \& Norris, 2006; Tripati \& Elderfield, 2005). Hosing experiments in two climate models (CCSM3 and GENIE) show that stratification can lead to a severe loss of oxygen in the South Atlantic and Indian Oceans (Zhou et al., 2016). Oxic conditions before the PETM are consistent with our $\mathrm{Cr}$ isotope data and recent magnetofossil data (Chang et al., 2018) but are in disagreement with trace metal geochemical data (Chun et al., 2010; Pälike et al., 2014 and Zhou et al., 2016). A difference in standard reduction potentials between $\mathrm{CrO}_{4}{ }^{2-}, \mathrm{MnO}_{2}, \mathrm{Ce}^{4+}$ and $\mathrm{UO}_{2}\left(\mathrm{CO}_{3}\right)_{3}{ }^{4-}$ may cause this apparent discrepancy.

The smaller magnitude of the $\delta^{53} \mathrm{Cr}$ excursion at ODP Site 1210 compared to the other sites (Figure 2) indicates less intense deoxygenation in the subtropical Pacific gyre than in the Atlantic Ocean. The oligotrophic environment, which would have been increased due to higher stratification during the PETM compared to background, in combination with the position of the $\delta^{53} \mathrm{Cr}$ peak within the acme of warming indicated by benthic $\delta^{18} \mathrm{O}$ (Tripati \& Elderfield, 2005; Zachos et al., 2003) suggests the $\delta^{53} \mathrm{Cr}$ anomaly can be attributed mainly to ocean warming driving decreased oxygen solubility. Our model-data reconstruction also suggests that deoxygenation across the PETM was due to warming resulting from a threefold to sixfold increase in atmospheric $\mathrm{CO}_{2}$. It must be noted that alternatively the model is very sensitive to nutrient fluxes and therefore only a small increase in nutrient runoff would create a similar effect. This interpretation would support studies showing increases in weathering (e.g., Dickson et al., 2015; Gavrilov et al., 2003; John et al., 2008; Ravizza et al., 2001) although it is not clear whether the increased runoff, increasing productivity in coastal sites, made it out into the open ocean (e.g., Carmichael et al., 2017; Gibbs et al., 2006). The switch to North Pacific deep water formation as discussed earlier can explain the more pronounced change in $[\mathrm{Cr}]$ than in $\delta^{53} \mathrm{Cr}$ during the CIE due to a decreased transport of $\mathrm{Cr}$ to the open ocean. $\mathrm{Mn}_{\mathrm{EF}}$ and $\mathrm{U}_{\mathrm{EF}}$ support the observation from $\delta^{53} \mathrm{Cr}$ and $\mathrm{Ce} / \mathrm{Ce}$ * that Pacific intermediate waters remained oxic (Pälike et al., 2014). The recovery in $\delta^{53} \mathrm{Cr}$ at ODP Site 1210 was rapid as intermediate waters cool.

\subsection{Evolution of Deoxygenation}

To pinpoint a source for the introduction of reduced carbon during the PETM, it is imperative to assess the timing of deoxygenation occurring at each of the sites. In the Bay of Biscay (DSDP 401), near the proposed 
site of biogenic methane injection and volcanism, $\delta^{53} \mathrm{Cr}$ values become more positive prior to the CIE and peak 9,000 years before the onset of the PETM (Figure 2a) and are corroborated by a drop in Cr concentrations. $\mathrm{Ce} / \mathrm{Ce}^{*}$ attain anoxic values $\left(\mathrm{Ce} / \mathrm{Ce}^{*}>1\right)$ at the same time approximately 9,000 years before the onset of the PETM (Figure 2c). It is possible that sediments deposited just prior to the PETM at DSDP Site 401 may have been influenced by interstitial fluid flow during the PETM, which could also partially explain why the redox response at this location occurred prior to the PETM. However, there is currently no sedimentological evidence to support this. Chromium isotope values in the Pacific (ODP Site 1210) peak $20 \mathrm{kyr}$ after the CIE onset, during maximum warmth (McCarren et al., 2008; Figure 2a). The timing of deoxygenation and response of $\delta^{53} \mathrm{Cr}$ at Walvis Ridge cannot be determined due to the severe carbonate dissolution during the onset and main body of the PETM at this site. However, fish teeth Ce/Ce* data from Zhou et al. (2016) along with foraminiferal Ce/Ce* from this study suggest peak anoxia in the South Atlantic occurred approximately 35-45 kyr after the onset of the PETM. Importantly, deoxygenation in the Pacific occurred before that in the South Atlantic as shown by $\delta^{53} \mathrm{Cr}$ at ODP Site 1210 on Shatsky Rise in the North Pacific (Figure 2) and Ce/Ce* at ODP Site 1263 on Walvis Ridge in the South Atlantic (Chun et al., 2010; Zhou et al., 2016) making the interpretation of a dissipation of the signal due to circulation impossible. Our model-data comparison reinforces previous suggestions that anoxia developed more easily in the Tethys Sea and Atlantic Ocean than in the Pacific Ocean during the PETM (Chun et al., 2010; Pälike et al., 2014; Zhou et al., 2016) with conditions of anoxia and hypoxia present in these basins even under pre-PETM conditions. However, our model-data comparison (Figure 4) shows that during the PETM the Pacific Ocean experienced some deoxygenation reaching oxic-hypoxic conditions in the North Pacific Ocean and hypoxia in the eastern Pacific Ocean.

\subsection{Temperature Control on Open Ocean Deoxygenation}

Comparing the maximum observed excursion size in $\delta^{53} \mathrm{Cr}$ during the PETM against the maximum carbon and benthic oxygen isotope excursions (CIE and OIE, respectively) illustrates that the size of the carbon cycle perturbation does not appear to have an impact on the size of the observed $\delta^{53} \mathrm{Cr}$ excursion (Figures 2 and 3). In contrast, a positive correlation is found with the magnitude of the benthic OIE, implying that warming exerts significant control on the size of the $\delta^{53} \mathrm{Cr}$ perturbation and by extrapolation over the expansion of open ocean low-oxygen environments during the Late Palaeocene to Early Eocene. As the $\delta^{53} \mathrm{Cr}$ records are incomplete for ODP Sites 401 and 1263, these correlations need to be approached with caution and may underestimate the Cr excursion. Additionally, when considering vital effects, the shifts in the foraminiferal $\delta^{53} \mathrm{Cr}$ likely slightly overestimate environmental changes (Remmelzwaal et al., 2019), since the maximum test size of planktic foraminifera may have increased by up to $150 \mu \mathrm{m}$ during the PETM depending on the foraminiferal species although overall decreases in test size have also been reported (Alegret et al., 2010; Kaiho et al., 2006; Petrizzo, 2007). Based on Remmelzwaal et al. (2019), the change in $\delta^{53} \mathrm{Cr}$ composition associated with the increase in foraminiferal test size and assemblage could account for a maximum of $+0.1 \%$ o to $+0.3 \%$ of the $\mathrm{Cr}$ isotope signal during the PETM depending on the test shape if a test increase is assumed. However, size changes in the foraminiferal assemblage have not yet been quantified. These factors affecting $\mathrm{Cr}$ isotopes do not impede converting the benthic OIE into temperature-associated dissolved oxygen loss (Broecker \& Peng, 1982). This shows that thermal effects account for a loss of -13.0 to $-32.7 \mu \mathrm{mol} / \mathrm{kg} \mathrm{O}_{2}$ at the study sites, which by itself is not enough to produce hypoxia. Warming will have additionally increased microbial metabolic rates (Pörtner et al., 2014). It has been suggested that the open ocean experienced increased oligotrophy during the PETM (Gibbs et al., 2006). This, however, would not necessarily imply less biological and biogeochemical activity (Ma et al., 2014). In combination with increased metabolic rates and more extensive remineralization, a constant or even decreasing primary productivity in the open ocean could have resulted in amplifying deoxygenation associated with warming of the ocean through increased export productivity. We suggest that warming of intermediate waters was one of the principal drivers of deoxygenation during the PETM with the scale of warming $\left(\sim 5{ }^{\circ} \mathrm{C}\right.$; Dunkley-Jones et al., 2013) producing widespread hypoxia throughout the North and South Atlantic. Our findings align with modern observations that warming is a major controlling factor on open ocean deoxygenation (Schmidtko et al., 2017). The extent of deoxygenation during the PETM shows that rapid temperature increases have caused widespread open ocean hypoxia in the past and that future oceans may also experience widespread deoxygenation due to anthropogenic global warming. 


\section{Conclusions}

This study shows that foraminiferal $\delta^{53} \mathrm{Cr}$ during the Late Paleocene and Early Eocene is controlled by local factors contributing to seawater deoxygenation, which is in line with the heterogeneity of $\mathrm{Cr}$ in modern oceans and its comparatively short residence time. Our model output indicates that deoxygenation was widespread throughout the global oceans during the PETM, while our Cr data sets add valuable information on local variation in bottom water deoxygenation. We attribute the deoxygenation mainly to rising temperatures in intermediate ocean waters due to higher atmospheric $\mathrm{CO}_{2}$, based on an apparent correlation between the magnitude of the benthic oxygen isotope and the $\mathrm{Cr}$ isotope excursions. Warmer intermediate waters, an increased microbial loop and remineralization, and declines in oxygen solubility jointly are suggested to have caused the lower oxygen concentrations. If any geographical spreading of deoxygenation occurred, it appears to have originated in the North Atlantic (DSDP Site 401), in line with evidence for this basin having been proximal to the location of injection of reduced carbon (Svensen et al., 2004). Chromium isotope values and Ce anomalies at ODP Site 1210 indicate this site may have been less impacted by deoxygenation than the two Atlantic sites.

\section{Acknowledgments}

This work was supported by NERC studentship 1509236 awarded to S. R. and NERC grant NE/H006443/1 awarded to R. H. J., I. J. P., and C. P.; the Wolfson Research Merit Award from the Royal Society to DNS; and by NERC research fellowship NE/J019062/1 awarded to F. M. M. The authors would like to express their gratitude to Kirsty Edgar, Sam Hammond, Sarah Greene, and Richard Pancost for their invaluable help and would like to thank Richard Norris and the International Ocean Discovery Program for sharing samples. Data supporting the conclusions of this study can be found in the supporting information.

\section{References}

Abbott, A. N., Haley, B. A., Tripati, A. K., \& Frank, M. (2016). Constraints on ocean circulation at the Paleocene-Eocene Thermal Maximum from neodymium isotopes. Climate of the Past, 12(4), 837-847. https://doi.org/10.5194/cp-12-837-2016

Alegret, L., Ortiz, S., Arenillas, I., \& Molina, E. (2010). What happens when the ocean is overheated? The foraminiferal response across the Paleocene-Eocene Thermal Maximum at the Alamedilla section (Spain). GSA Bulletin, 122(9-10), 1616-1624. https://doi.org/10.1130/B30055.1 Alexander, K., Meissner, K. J., \& Bralower, T. J. (2015). Sudden spreading of corrosive bottom water during the Palaeocene-Eocene Thermal Maximum. Nature Geoscience, 8(6), 458-461. https://doi.org/10.1038/ngeo2430

Barker, S., Greaves, M., \& Elderfield, H. (2003). A study of cleaning procedures used for foraminiferal Mg/Ca paleothermometry. Geochemistry, Geophysics, Geosystems, 4(9), 8407. https://doi.org/10.1029/2003GC000559

Bice, K. L., \& Marotzke, J. (2002). Could changing ocean circulation have destabilized methane hydrate at the Paleocene/Eocene boundary? Paleoceanography, 17(2), 1018. https://doi.org/10.1029/2001PA000678

Bonnand, P., James, R. H., Parkinson, I. J., Connelly, D. P., \& Fairchild, I. J. (2013). The chromium isotopic composition of seawater and marine carbonates. Earth and Planetary Science Letters, 382, 10-20. https://doi.org/10.1016/j.epsl.2013.09.001

Bonnand, P., Parkinson, I. J., James, R. H., Karjalainen, A.-M., \& Fehr, M. A. (2011). Accurate and precise determination of stable Cr isotope compositions in carbonates by double spike MC-ICP-MS. Journal of Analytical Atomic Spectrometry, 26(3), 528-535. https://doi. org/10.1039/c0ja00167h

Broecker, W. S., \& Peng, T. H. (1982). Tracers in the sea. New York: Lamont Doherty Geological Observatory, Columbia University.

Brookins, D. G. (1988). Eh-pH Diagrams for Geochemistry. Berlin, Heidelberg: Springer-Verlag. https://doi.org/10.1007/978-3-642-73093-1

Carmichael, M. J., Inglis, G. N., Badger, M. P. S., Naafs, B. D. A., Behrooz, L., Remmelzwaal, S., et al. (2017). Hydrological and associated biogeochemical consequences of rapid global warming during the Paleocene-Eocene Thermal Maximum. Global and Planetary Change, 157, 114-138. https://doi.org/10.1016/j.gloplacha.2017.07.014

Chang, L., Harrison, R. J., Zeng, F., Berndt, T. A., Roberts, A. P., Heslop, D., \& Zhao, X. (2018). Coupled microbial bloom and oxygenation decline recorded by magnetofossils during the Palaeocene-Eocene Thermal Maximum. Nature Communications, 9(1), 4007. https://doi. org/10.1038/s41467-018-06472-y

Chun, C. O. J., Delaney, M. L., \& Zachos, J. C. (2010). Paleoredox changes across the Paleocene-Eocene thermal maximum, Walvis Ridge (ODP Sites 1262, 1263, and 1266): Evidence from Mn and U enrichment factors. Paleoceanography, 25, PA4202. https://doi.org/10.1029/2009PA001861

Colosimo, A. B., Bralower, T. J., \& Zachos, J. C. (2006). Evidence for lysocline shoaling at the Paleocene/Eocene Thermal Maximum on Shatsky Rise, northwest Pacific. In: Bralower, T. J., Premoli Silva, Malone M. J. (Eds.), 2006. Proceedings of the Ocean Drilling Program, Scientific Results, 198: College Station, TX (Ocean Drilling Program).

Cramer, B. S., Wright, J. D., Kent, D. V., \& Aubry, M.-P. (2003). Orbital climate forcing of $\delta^{13}$ C excursions in the late Paleocene-early Eocene (chrons C24n-C25n). Paleoceanography, 18(4), 1097. https://doi.org/10.1029/2003PA000909

Cranston, R. E., \& Murray, J. W. (1978). The determination of chromium species in natural waters. Analytica Chimica Acta, 99(2), 275-282. https://doi.org/10.1016/S0003-2670(01)83568-6

de Baar, H. J. W., German, C. R., Elderfield, H., \& Vangaans, P. (1988). Rare-earth element distributions in anoxic waters of the Cariaco Trench. Geochimica et Cosmochimica Acta, 52(5), 1203-1219. https://doi.org/10.1016/0016-7037(88)90275-X

Diaz, R. J., \& Rosenberg, R. (2008). Spreading dead zones and consequences for marine ecosystems. Science, 321(5891), 926-929. https:// doi.org/10.1126/science.1156401

Dickson, A. J., Cohen, A. S., \& Coe, A. L. (2012). Seawater oxygenation during the Paleocene-Eocene Thermal Maximum. Geology, 40(7), 639-642. https://doi.org/10.1130/G32977.1

Dickson, A. J., Cohen, A. S., \& Coe, A. L. (2014). Continental margin molybdenum isotope signatures from the early Eocene. Earth and Planetary Science Letters, 404, 389-395. https://doi.org/10.1016/j.epsl.2014.08.004

Dickson, A. J., Cohen, A. S., Coe, A. L., Davies, M., Shcherbinina, E. A., \& Gavrilov, Y. O. (2015). Evidence for weathering and volcanism during the PETM from Arctic Ocean and Peri-Tethys osmium isotope records. Palaeogeography, Palaeoclimatology, Palaeoecology, 438, 300-307. https://doi.org/10.1016/j.palaeo.2015.08.019

Dunkley-Jones, T., Lunt, D. J., Schmidt, D. N., Ridgwell, A., Sluijs, A., Valdes, P. J., \& Maslin, M. (2013). Climate model and proxy data constraints on ocean warming across the Paleocene-Eocene Thermal Maximum. Earth-Science Reviews, 125, 123-145. https://doi.org/ 10.1016/j.earscirev.2013.07.004

Economou-Eliopoulos, M., Frei, R., \& Megremi, I. (2016). Potential leaching of Cr (VI) from laterite mines and residues of metallurgical products (red mud and slag): an integrated approach. Journal of Geochemical Exploration, 162, 40-49. https://doi.org/10.1016/j. gexplo.2015.12.007 
Ellis, A. S., Johnson, T. M., \& Bullen, T. D. (2002). Chromium isotopes and the fate of hexavalent chromium in the environment. Science, 295(5562), 2060-2062. https://doi.org/10.1126/science.1068368

Gavrilov, Y., Shcherbina, E. A., \& Oberhänsli, H. (2003). Paleocene-Eocene boundary events in the northeastern Peri-Tethys. In S. L. Wing, et al. (Eds.), Causes and consequences of globally warm climates in the early Paleogene (Vol. 369, pp. 147-168). Geological Society of America Special Paper. https://doi.org/10.1130/0-8137-2369-8.147

Gibbs, S. J., Bralower, T. J., Bown, P. R., Zachos, J. C., \& Bybell, L. M. (2006). Shelf and open-ocean calcareous phytoplankton assemblages across the Paleocene-Eocene Thermal Maximum: Implication for global productivity gradients. Geology, 34(4), 233-236. https://doi.org/ $10.1130 / \mathrm{G} 22381.1$

Goring-Harford, H., Klar, J. K., Pearce, C. R., Connelly, D. P., Achterberg, E. P., \& James, R. H. (2018). Behaviour of chromium isotopes in the eastern sub-tropical Atlantic Oxygen Minimum Zone. Geochimica et Cosmochimica Acta, 236, 41-59. https://doi.org/10.1016/j. gca.2018.03.004

Gutjahr, M., Ridgwell, A., Sexton, P. F., Anagnostou, E., Pearson, P. N., Pälike, H., et al. (2017). Very large release of mostly volcanic carbon during the Palaeocene-Eocene Thermal Maximum. Nature, 548(7669), 573-577. https://doi.org/10.1038/nature23646

Haley, B. A., Klinkhammer, G. P., \& McManus, J. (2004). Rare earth elements in pore waters of marine sediments. Geochimica et Cosmochimica Acta, 68(6), 1265-1279. https://doi.org/10.1016/j.gca.2003.09.012

Hein, J. R., \& Koschinsky, A. (2014). Deep-ocean ferromanganese crusts and nodules. In H. D. Holland \& K. K. Turekian (Eds.), Treatise on Geochemistry (2nd ed., pp. 273-291). Oxford: Elsevier. https://doi.org/10.1016/B978-0-08-095975-7.01111-6

Holmden, C., Jacobson, A., Sageman, B., \& Hurtgen, M. (2016). Response of the Cr isotope proxy to Cretaceous ocean anoxic event 2 in a pelagic carbonate succession from the Western Interior Seaway. Geochimica et Cosmochimica Acta, 186, 277-295. https://doi.org/ 10.1016/j.gca.2016.04.039

John, C. M., Bohaty, S. M., Zachos, J. C., Sluijs, A., Gibbs, S., Brinkhuis, H., \& Bralower, T. J. (2008). North American continental margin records of the Paleocene-Eocene thermal maximum: Implications for global carbon and hydrological cycling. Paleoceanography, 23, PA2217. https://doi.org/10.1029/2007PA001465

Kaiho, K., Takeda, K., Petrizzo, M. R., \& Zachos, J. C. (2006). Anomalous shifts in tropical Pacific planktonic and benthic foraminiferal test size during the Paleocene-Eocene thermal maximum. Palaeogeography, Palaeoclimatology, Palaeoecology, 237(2-4), 456-464. https://doi. org/10.1016/j.palaeo.2005.12.017

Keeling, R. F., Körtzinger, A., \& Gruber, N. (2010). Ocean deoxygenation in a warming world. Annual Reviews of Marine Science, 2(1), 199-229. https://doi.org/10.1146/annurev.marine.010908.163855

Kelly, D. C., Nielsen, T. M. J., McCarren, H. K., Zachos, J. C., \& Röhl, U. (2010). Spatiotemporal patterns of carbonate sedimentation in the South Atlantic: Implications for carbon cycling during the Paleocene-Eocene thermal maximum. Palaeogeography, Palaeoclimatology, Palaeoecology, 293(1-2), 30-40. https://doi.org/10.1016/j.palaeo.2010.04.027

Kelly, D. C., Zachos, J. C., Bralower, T. J., \& Schellenberg, S. A. (2005). Enhanced terrestrial weathering/runoff and surface ocean carbonate production during the recovery stages of the Paleocene-Eocene thermal maximum. Paleoceanography, 20, PA4023. https://doi.org/ 10.1029/2005PA001163

Lunt, D. J., Valdes, P. J., Jones, T. D., Ridgwell, A., Haywood, A. M., Schmidt, D. N., et al. (2010). $\mathrm{CO}_{2}$-driven ocean circulation changes as an amplifier of Paleocene-Eocene thermal maximum hydrate destabilization. Geology, 38(10), 875-878. https://doi.org/10.1130/ G31184.1

Ma, Z., Gray, E., Thomas, E., Murphy, B., Zachos, J., \& Paytan, A. (2014). Carbon sequestration during the Palaeocene-Eocene Thermal Maximum by an efficient biological pump. Nature Geoscience, 7(5), 382-388. https://doi.org/10.1038/ngeo2139

McCarren, H., Thomas, E., Hasegawa, T., Röhl, U., \& Zachos, J. C. (2008). Depth dependency of the Paleocene-Eocene carbon isotope excursion: Paired benthic and terrestrial biomarker records (ocean drilling program leg 208, Walvis Ridge). Geochemistry, Geophysics, Geosystems, 9, Q10008. https://doi.org/10.1029/2008GC002116

Monteiro, F. M., Pancost, R. D., Ridgwell, A., \& Donnadieu, Y. (2012). Nutrients as the dominant control on the spread of anoxia and euxinia across the Cenomanian-Turonian oceanic anoxic event (OAE2): Model-data comparison. Paleoceanography, 27, PA4209. https://doi.org/10.1029/2012PA002351

Nicolo, M. J., Dickens, G. R., \& Hollis, C. J. (2010). South Pacific intermediate water oxygen depletion at the onset of the PaleoceneEocene thermal maximum as depicted in New Zealand margin sections. Paleoceanography, 25, PA4210. https://doi.org/10.1029/ 2009PA001904

Nunes, F., \& Norris, R. D. (2006). Abrupt reversal in ocean overturning during the Palaeocene/Eocene warm period. Nature, 439(7072), 60-63. https://doi.org/10.1038/nature04386

Pälike, C., Delaney, M. L., \& Zachos, J. C. (2014). Deep-sea redox across the Paleocene-Eocene thermal maximum. Geochemistry, Geophysics, Geosystems, 15, 1038-1053. https://doi.org/10.1002/2013GC005074

Palmer, M. R. (1985). Rare earth elements in foraminifera tests. Earth and Planetary Science Letters, 73(2-4), 285-298. https://doi.org/ $10.1016 / 0012-821 X(85) 90077-9$

Pardo, A., Keller, G., Molina, E., \& Canudo, J. (1997). Planktic foraminiferal turnover across the Paleocene-Eocene transition at DSDP Site 401, Bay of Biscay, North Atlantic. Marine Micropaleontology, 29(2), 129-158. https://doi.org/10.1016/S0377-8398(96)00035-7

Paulukat, C., Gilleaudeau, G. J., Chernyavskiy, P., \& Frei, R. (2016). The Cr-isotope signature of surface seawater: A global perspective. Chemical Geology, 444, 101-109. https://doi.org/10.1016/j.chemgeo.2016.10.004

Penman, D. E., Hönisch, B., Zeebe, R. E., Thomas, E., \& Zachos, J. C. (2014). Rapid and sustained surface ocean acidification during the Paleocene-Eocene Thermal Maximum. Paleoceanography, 29, 357-369. https://doi.org/10.1002/2014PA002621

Penman, D. E., Turner, S. K., Sexton, P. F., Norris, R. D., Dickson, A. J., Boulila, S., et al. (2016). An abyssal carbonate compensation depth overshoot in the aftermath of the Palaeocene-Eocene Thermal Maximum. Nature Geoscience, 9(8), 575-580. https://doi.org/10.1038/ ngeo 2757

Pereira, N. S., Voegelin, A. R., Paulukat, C., Sial, A. N., Ferreira, V. P., \& Frei, R. (2016). Chromium-isotope signatures in scleractinian corals from the Rocas Atoll, tropical South Atlantic. Geobiology, 14(1), 54-67. https://doi.org/10.1111/gbi.12155

Petrizzo, M. R. (2007). The onset of the Paleocene-Eocene Thermal Maximum (PETM) at Sites 1209 and 1210 (Shatsky Rise, Pacific Ocean) as recorded by planktonic foraminifera. Marine Micropaleontology, 63(3-4), 187-200. https://doi.org/10.1016/j. marmicro.2006.11.007

Pörtner, H.-O., Karl, D. M., Boyd, P. W., Cheung, W. W. L., Lluch-Cota, S. E., Nojiri, Y., et al. (2014). Ocean systems. In C. B. Field, et al. (Eds.), Climate Change 2014: Impacts, Adaptation, and Vulnerability. Part A: Global and Sectoral Aspects. Contribution of Working Group II to the Fifth Assessment Report of the Intergovernmental Panel on Climate Change (pp. 411-484). Cambridge, UK and New York: Cambridge University Press. 
Post, J. E., Thomas, E., \& Heaney, P. J. (2016). Jianshuiite in oceanic manganese nodules at the Paleocene-Eocene boundary. American Mineralogist, 101(2), 407-414. https://doi.org/10.2138/am-2016-5347

Qin, L., \& Wang, X. (2017). Chromium isotope geochemistry. Reviews in Mineralogy \& Geochemistry, 82(1), 379-414. https://doi.org/ 10.2138/rmg.2017.82.10

Ravizza, G., Norris, R. N., Blusztajn, J., \& Aubry, M.-P. (2001). An osmium isotope excursion associated with the late Paleocene thermal maximum: evidence of intensified chemical weathering. Paleoceanography, 16(2), 155-163. https://doi.org/10.1029/2000PA000541

Reinhard, C. T., Planavsky, N. J., Wang, X., Fischer, W. W., Johnson, T. M., \& Lyons, T. W. (2014). The isotopic composition of authigenic chromium in anoxic marine sediments: A case study from the Cariaco basin. Earth and Planetary Science Letters, 407, 9-18. https://doi. org/10.1016/j.epsl.2014.09.024

Remmelzwaal, S. R. C., Sadekov, A. Y., Parkinson, I. J., Schmidt, D. N., Titelboim, D., Abramovich, S., et al. (2019). Post-depositional overprinting of chromium in foraminifera. Earth and Planetary Science Letters, 515, 100-111. https://doi.org/10.1016/j.epsl.2019.03.001

Ridgwell, A., Hargreaves, J. C., Edwards, N. R., Annan, J. D., Lenton, T. M., Marsh, R., et al. (2007). Marine geochemical data assimilation in an efficient Earth System Model of global biogeochemical cycling. Biogeosciences, 4(1), 87-104. https://doi.org/10.5194/bg-4-87-2007

Röhl, U., Westerhold, T., Bralower, T. J., \& Zachos, J. C. (2007). On the duration of the Paleocene-Eocene thermal maximum (PETM). Geochemistry Geophysics Geosystems, 8, Q12002. https://doi.org/10.1029/2007GC001784

Scheiderich, K., Amini, M., Holmden, C., \& Francois, R. (2015). Global variability of chromium isotopes in seawater demonstrated by Pacific, Atlantic, and Arctic Ocean samples. Earth and Planetary Science Letters, 423, 87-97. https://doi.org/10.1016/j.epsl.2015.04.030

Schmidtko, S., Stramma, L., \& Visbeck, M. (2017). Decline in global oceanic oxygen content during the past five decades. Nature, 542(7641), 335-339. https://doi.org/10.1038/nature21399

Schubert, B. A., \& Hope Jahren, A. (2013). Reconciliation of marine and terrestrial carbon isotope excursions based on changing atmospheric $\mathrm{CO}_{2}$ levels. Nature Communications, 4(1653). https://doi.org/10.1038/ncomms2659

Svensen, H., Planke, S., Malthe-Sørenssen, A., Jamtveit, B., Myklebust, R., Eidem, T. R., \& Rey, S. S. (2004). Release of methane from a volcanic basin as a mechanism for initial Eocene global warming. Nature, 429(6991), 542-545. https://doi.org/10.1038/nature02566

Tang, Y., Elzinga, E. J., Lee, Y. J., \& Reeder, R. J. (2007). Coprecipitation of chromate with calcite: Batch experiments and X-ray absorption spectroscopy. Geochimica et Cosmochimica Acta, 71(6), 1480-1493. https://doi.org/10.1016/j.gca.2006.12.010

Taylor, S. R., \& McLennan, S. M. (1985). The continental crust: Its composition and evolution. Blackwell Scientific.

Tostevin, R., Shields, G. A., Tarbuck, G. M., He, T., Clarkson, M. O., \& Wood, R. A. (2016). Effective use of cerium anomalies as a redox proxy in carbonate-dominated marine settings. Chemical Geology, 438, 146-162. https://doi.org/10.1016/j.chemgeo.2016.06.027

Tripati, A., \& Elderfield, H. (2005). Deep-sea temperature and circulation changes at the Paleocene-Eocene Thermal Maximum. Science, 308(5730), 1894-1898. https://doi.org/10.1126/science.1109202

Vaquer-Sunyer, R., \& Duarte, C. M. (2008). Thresholds of hypoxia for marine biodiversity. Proceedings of the National Academy of Sciences, 105(40), 15,452-15,457. https://doi.org/10.1073/pnas.0803833105

Wang, X., Planavsky, N. J., Hull, P. M., Tripati, A. E., Zou, H. J., Elder, L., \& Henehan, M. (2017). Chromium isotopic composition of coretop planktonic foraminifera. Geobiology, 15(1), 51-64. https://doi.org/10.1111/gbi.12198

Westerhold, T., Röhl, U., Donner, B., McCarren, H. K., \& Zachos, J. C. (2011). A complete high-resolution Paleocene benthic stable isotope record for the central Pacific (ODP Site 1209). Paleoceanography, 26, PA2216. https://doi.org/10.1029/2010PA002092

Westerhold, T., Röhl, U., McCarren, H. K., \& Zachos, J. C. (2009). Latest on the absolute age of the Paleocene-Eocene Thermal Maximum (PETM): New insights from exact stratigraphic position of key ash layers +19 and -17. Earth and Planetary Science Letters, 287(3-4), 412-419. https://doi.org/10.1016/j.epsl.2009.08.027

Westerhold, T., Röhl, U., Raffi, I., Fornaciari, E., Monechi, S., Reale, V., et al. (2008). Astronomical calibration of the Paleocene time. Palaeogeography, Palaeoclimatology, Palaeoecology, 257(4), 377-403. https://doi.org/10.1016/j.palaeo.2007.09.016

Zachos, J. C., Röhl, U., Schellenberg, S. A., Sluijs, A., Hodell, D. A., Kelly, D. C., et al. (2005). Rapid acidification of the ocean during the Paleocene-Eocene thermal maximum. Science, 308(5728), 1611-1615. https://doi.org/10.1126/science.1109004

Zachos, J. C., Wara, M. W., Bohaty, S., Delaney, M. L., Petrizzo, M. R., Brill, A., et al. (2003). A transient rise in tropical sea surface temperature during the Paleocene-Eocene thermal maximum. Science, 302(5650), 1551-1554. https://doi.org/10.1126/science.1090110

Zeebe, R. E., Ridgwell, A., \& Zachos, J. C. (2016). Anthropogenic carbon release rate unprecedented during the past 66 million years. Nature Geoscience, 9(4), 325-329. https://doi.org/10.1038/NGEO2681

Zhou, X., Thomas, E., Winguth, A. M. E., Ridgwell, A., Scher, H., Hoogakker, B. A. A., et al. (2016). Expanded oxygen minimum zones during the late Paleocene early Eocene: Hints from multiproxy comparison and ocean modeling. Paleoceanography, 31, $1532-1546$. https://doi.org/10.1002/2016PA003020 